\title{
The Right to Know the Truth in the Light of the Right to Privacy: The Case of Victims of the Communist Regime in Europe
}

\author{
Edita Gruodytè \\ Silvija Gervienè \\ Faculty of Law, \\ Vytautas Magnus University \\ Jonava Street 66 \\ Kaunas LT-3000, Lithuania \\ E-mail: edita.gruodyte@vdu.It \\ E-mail: silvijag29@gmail.com
}

Abstract: The right to know the truth is established as one of the rights constituting the right to effective remedy but in post-Communist countries this right is limited to victims of the Communist regime because of failure to access the files of former secret services on two different grounds: certain victim's information is protected as personal data on the grounds of privacy rights and certain files are still kept as a classified information. Thus, the article analyses if such limitations in postCommunist countries are compatible with Article 8 of the European Convention on Human Rights. The answer is provided using mainly an analysis of the case law of the European Court of Human Rights. Lithuania as a case study was chosen for the analysis in a situation where certain files are kept as classified information.

Keywords: access to the files, post-Communist countries, private life, right to know the truth, victim

\section{Introduction}

The right to know the truth is established as one of the rights constituting the right to effective remedy in the Basic Principles and Guidelines on the Right to a Remedy and Reparation for Victims of Gross Violations of International 
Human Rights Law and Serious Violations of International Humanitarian Law (hereinafter Basic Principles or BP) (UN General Assembly, 2005). The application of this right after the collapse of the Communist regime in Europe in the case of the victims of the Communist regime (hereinafter Victims) was discussed in the previous research of the authors, giving special attention to the abilities to access the files of former secret services (hereinafter Files or Archives) in post-Communist countries. ${ }^{1}$ As the Basic Principles is a "soft law" document, there is a need to identify whether Victim's right to truth can be defended as an obligation of a state stemming from its commitment to protect human rights. ${ }^{2}$ Here the possibility of invocation of the right to private life will be discussed because abuses of human rights committed by secret services usually affect one's personality and life, thus the question emerges whether right to truth can also be covered by obligation to protect private life.

The goal of this article is to identify whether Victim's right to private life is not infringed when his or her right to know the truth / to access Files is limited: (1) in the interests of other interested parties (other Victims); (2) in the interests of national security (classified information). ${ }^{3}$ The first part of the article analyses if Victim's inability to access the Files falls within the concept of private life as provided in Article 8 of the European Convention on Human Rights (ECHR). ${ }^{4}$ This article is designed to protect private and family life, home and correspondence. Here the issue of private life will be considered in particular, leaving aside the other concepts. The second section of the article deals with restrictions to access the Files in the light of the

1 The article 'Access to archives in the post-Communist countries: the victim's perspective' revealed that Victims failed to access the Files because of two different grounds: certain Victim's information is protected as a personal data on the grounds of privacy rights, and certain Files are still kept as a classified information. See Gruodytè \& Gervienè, 2015.

2 For a more detailed discussion on this issue see Kerikmäe, Hamulak \& Chochia, 2016, see also Nyman-Metcalf, 2014.

3 It is obvious that any disclosure of personal information raises the issue of possible infringement of privacy rights but the object of this article is a non-disclosure of information in connection with the right to respect for private life. Thus the issue here is taken from the perspective of Victim, who was granted no access.

4 Article 8 of the European Convention on Human Rights reads as follows:

1. Everyone has the right to respect for his private and family life, his home and his correspondence.

2. There shall be no interference by a public authority with the exercise of this right except such as is in accordance with the law and is necessary in a democratic society in the interests of national security, public safety or the economic wellbeing of the country, for the prevention of disorder or crime, for the protection of health or morals, or for the protection of the rights and freedoms of others. 
respect for private life, evaluating both issues and interests of other Victims and matters of national security.

In this article, the choice of the European Convention on Human Rights as a point of departure in shaping the concept of private life and the right to its respect is justified by the prominence of the Convention in enforcement of human rights. The latter phenomenon is described "as a predominantly European concept" (Kerikmäe \& Nyman-Metcalf, 2014, p. 272) and this article in particular deals with the Victim's right to truth after the collapse of the Communist regime in Europe. ${ }^{5}$ Moreover almost all post-Communist countries in Europe are now members of the Council of Europe (Council of Europe, 2017a) and participants of European Convention on Human Rights (Council of Europe, 2017b).

Methodologically, the main instrument is the analysis of the case law developed by the European Court of Human Rights (hereinafter ECHR or the Court) and academic literature. The established concepts are further applied to particular post-Communist countries, representing examples of both models - either full or limited access. However, to present a situation of certain Files being kept as classified information, Lithuania is chosen as a case study because of the necessity to address the individual features of the national security system of each post-Communist country.

\section{Inability to access the Files as an issue of private life}

In the study specifically addressing the right to the truth that was prepared by the Commission on Human Rights acting within the Economic and Social Council on the United Nations, the link of the right to the truth was established with such human rights as the right to family life, the right to due process, the right to be free from torture and ill-treatment and the right to seek and impart information (Commission on Human Rights, 2006, pp. 15). No link with the right to respect

5 In addition it should be stressed that Basic Principles "do not entail new international or domestic legal obligations but identify mechanisms, modalities, procedures and methods for the implementation of existing legal obligations under international human rights law and international humanitarian law" (UN General Assembly, 2005) and in the Preamble of this document, the European Convention on Human Rights is mentioned among other regional instruments establishing right to effective remedy (UN General Assembly, 2005). However Article 13 of the European Convention on Human Rights, providing right to effective remedy, can only be invoked if the "rights and freedoms as set forth in this Convention are violated" (ECHR, Article 13). Thus, Article 13 is applied only in conjunction with other articles of the Convention. 
for private life was mentioned. To establish whether such link exists, the notion of private life under the case law of the ECHR has to be revealed. Especially taking into account that the Court does not limit itself to an exhaustive definition of private life (e.g., Koch v. Germany [2012]; Couderc and Hachette Filipacchi Associés v. France [2015]; Nada v. Switzerland [2012]) and the Convention itself is interpreted in a dynamic manner although to a limited extent (Kerikmäe \& Nyman-Metcalf, 2012, pp. 42).

\subsection{The concept of private law in the case law of ECHR}

As the Court has not dealt yet with the issue discussed, certain guidelines could be found throughout the existing jurisprudence of the Court. Unfortunately, the case law is not very consistent as many issues are considered under this concept and the Court in each case elaborates only on certain elements relevant to a particular case or simply states that the circumstances of the case fall within the ambit of Article 8. This sometimes results in differences in descriptions of the same elements. However, a general picture still can be drawn. To sum up, the concept of private life is shaped through two basic components: physical and social identity and physical and psychological integrity. These components consist of several elements that are revealed further.

\subsubsection{Physical and social identity}

The content of physical and social identity is uncovered through elements of personal autonomy, personal development and establishment of relationships with other human beings and outside world (e.g., Tysiac v. Poland [2007]; Aksu v. Turkey [2012]; Evans v. the United Kingdom [2007]; Ternovszky v. Hungary [2010]; V.C. v. Slovakia [2011]; Haas v. Switzerland [2011]; Gillan and Quinton v. the United Kingdom [2010]), but the Court practice is not identical. Sometimes enumerated aspects are used to define the notion of private life itself not indicating the fact that a certain element relates to the physical and social identity as such (see, e.g., Munjaz v. the United Kingdom [2012]; Pretty v. the United Kingdom [2002]; Avram and others v. Moldova [2011]; E.B. v. France [2008]; Haas v. Switzerland [2011]). In some cases attention is given only to certain aspects relevant for a particular case (e.g., S.H. and others v. Austria [2011]; Costa And Pavan v. Italy [2012]; McDonald v. the United Kingdom [2014]) while in other circumstances severa ${ }^{6}$ or even

6 For example, the Court has found that protection of honour and reputation and watching TV may involve both elements: personal development and establishment of relationships with other human beings and outside world. See Oleksandr Volkov v. Ukraine [2013] ECHR no. 21722/11; Laduna v. Slovakia [2011] ECHR no. 31827/02. 
all three elements are discussed (e.g., Fernández Martínez v. Spain [2014]; M. and M. v. Croatia [2015]).

The principle of personal autonomy is defined by the ECHR as "an important principle underlying the interpretation of [...] guarantees [protected by Article 8]" (Pretty v. the United Kingdom [2002]; Fernández Martínez v. Spain [2014]; M. and M. v. Croatia [2015]; Aksu v. Turkey [2012]). Personal autonomy is perceived as the right to make choices as to how to lead one's own life, provided that this does not unjustifiably interfere with the rights and freedoms of others (e.g., M. and M. v. Croatia [2015]; Fernández Martínez v. Spain [2014]), or in particular, the ability to express ideas of self. This principle also encompasses the right to make choices about one's own body, especially when things believed to be inherent are taken into account, and the control of bodily functions (e.g., McDonald v. the United Kingdom [2014]; Pretty v. the United Kingdom [2002]; Koch v. Germany [2012]; Gross v. Switzerland [2013]). The sense of one's identity as an individual human being is also protected by this principle (e.g., Christine Goodwin v. the United Kingdom [2002]; Ciubotaru v. Moldova [2010]) and the Court has already pronounced that this includes ethnic identity (e.g., Aksu v. Turkey [2012]), gender identification, name, sexual orientation, sexual life and the right to respect for both the decisions to have and not to have a child (e.g., Ciubotaru v. Moldova [2010]; Bensaid v. the United Kingdom [2001]; Van Kuck v. Germany [2003]; E.B. v. France [2008]).

Meanwhile, personal development is usually described as the right to selfdetermination (e.g., E.B. v. France [2008]; A, B and C v. Latvia [2016]; S.H. and others v. Austria [2011]; Costa And Pavan v. Italy [2012]). This element is hard to isolate from the principle of personal autonomy especially as the Court itself sometimes describes personal development in terms of personality and personal autonomy (e.g., Reklos and Davourlis v. Greece [2009]). Here the right to an identity must also be taken into account because this right is defined in some cases as a matter of relevance to personal development (e.g., Odièvre v. France [2003]; Khmel v. Russia [2013]; Rothe v. Austria [2013]; Küchl v. Austria [2013]; Lillo-Stenberg and Scether v. Norway [2014]). The right to an identity first of all means the right to establish details of identity as individual human beings (e.g., Odièvre v. France [2003]; Christine Goodwin v. the United Kingdom [2002]; I. v. the United Kingdom [2002]). The Court has already stated that person's name, image (e.g., Khmel v. Russia [2013]; Rothe v. Austria [2013]; Küchl v. Austria [2013]; Reklos and Davourlis v. Greece [2009]; Couderc and Hachette Filipacchi Associés v. France [2015]; Lillo-Stenberg and Scether v. Norway [2014]), the right to know one's parentage and the circumstances of one's birth (e.g., Odièvre v. France [2003]; Godelli v. Italy [2013]) constitute 
the elements of identity. Thus a person must have control over details forming his identity. Taking everything into account, personal development means development, without outside interference, of the personality of each individual in his relations with other human beings (e.g., Von Hannover v. Germany (No. 2) [2012]).

This leads to the third element of physical and social identity-establishment of relationships with other human beings. The analysis of the case-law of the ECHR reveals that the Court does not want "to limit the notion of 'private life' to an 'inner circle' in which the individual may live his own personal life as he chooses and to exclude therefrom entirely the outside world not encompassed within that circle" (Niemietz v. Germany [1992]; Fernández Martínez v. Spain [2014]). However not every establishment of relationships with other human beings and outside world will be protected by Article 8 and the Court specifically states that "interpersonal relations of such broad and indeterminate scope that there can be no conceivable direct link between the action or inaction of a State and a person's private life" will not be protected. The case of criminal behavior also falls within this exception although even here, in certain cases, the issues of private life may also appear (Gough v. the United Kingdom [2015]). Thus, the possibility of approaching others in order to establish or develop relationships with other human beings or the zone of interaction between a person and others even in a public context could be treated as forming individual's private life especially when development of social identity is concerned (e.g., Campagnano v. Italy [2006]; Oleksandr Volkov v. Ukraine [2013]; Ihsan Ay v. Turkey [2014]; Fernández Martinez v. Spain [2014]; Avram and others v. Moldova [2011]; Gough v. the United Kingdom [2015]; Von Hannover v. Germany (No. 2) [2012]). The Court has already established that professional activities (e.g., Campagnano v. Italy [2006]; Oleksandr Volkov v. Ukraine [2013]), "the mere storing of data relating to the private life" by public authorities (e.g., S. and Marper v. the United Kingdom [2008]; Uzun v. Germany [2010]; Amann v. Switzerland [2000]) reflect the latter element within the concept of private life.

\subsubsection{Physical and psychological integrity}

The second aspect we should discuss when answering the first question is the content of physical and psychological/ moral integrity. The ECHR already provided some limits stating that "not every act or measure which adversely affects moral or physical integrity will interfere with the right to respect to private life guaranteed by Article" (Bensaid v. the United Kingdom [2001]). Under its case law, protection of person's physical and psychological integrity means protection of a person from criminal behaviour where fundamental 
values and essential aspects of private life are at stake, for example, such as rape and sexual abuse of children, and protection must be guaranteed through efficient criminal-law provisions, effective investigation and the possibility of obtaining reparation and redress (e.g., A, B and C v. Latvia [2016]). Other spheres where physical and psychological integrity of a person are at stake are protection of health of a person, either mental or physical (e.g., Bensaid v. the United Kingdom [2001]; Costello-Roberts v. the United Kingdom [1993]) and protection of person's ability to make decisions on his or her medical treatment (e.g., Glass v. the United Kingdom [2004]). Thus the physical and psychological integrity of a person will be considered as falling within a concept of private life if person's physical or mental health is affected so that a person is prevented from effective enjoyment of the right to respect for private life or a person is unable to make decisions about his or her medical treatment.

\subsection{Relation of the access to the Files and the established concept of private life}

The question arises how the contents of the private life as revealed by the ECHR are appropriate for explaining the issue of the right to the truth in post-Communist countries through access to the Files. On the basis of the analysis performed on the notion of private life under Article 8, it is evident that the activities of former secret services of the repressive regimes in the post-Communist countries (hereinafter Secret Services) affected establishment of relationships with other human beings and the outside world because Secret Services not only collected information concerning Victim's private life but even shaped it. The latter element is still present as this information is kept as records of a state after the collapse of the Communist regime. Here it is important to note that this article does not question the legitimacy of the storage of such records as they form an important part of the history and development of the post-Communist countries but questions the ways the state organises and controls access to these Files, especially by those who are considered Victims of the former regime.

The history on the scope of the activities of Secret Services reveals that up until the beginning of the $1960 \mathrm{~s}$, various forms of physical coercion, torture were used against Victims to collect the required information. Later this transformed into psychological pressure, although physical coercion remained as a working method in certain cases (Caparini, 2014; Mertelsmann \& Rahi-Tamm, 2009; Katamidze, 2007; Koehler, 1999). Secret Services usually gathered information on targeted persons using methods severely disturbing private life, for example, the use of hidden listening devices at home, interference with established 
personal relations, secret entrance to private premises, etc. (Ciobanu, 2014, pp. 1466; Caparini, 2014, pp. 500; Verdery, 2013, pp. 39-40; Burinskaite \& Okuličiūte, 2011; Koehler, 1999). All these methods were used without the person's knowledge and outside of his/her control. Such activities of Secret Services could be considered as affecting all elements forming the physical and social identity of a person within the concept of private life.

The gathered information was used to intimidate the targeted person, his or her family members and others in close relation with the targeted person (Mitroiu, 2016, p. 8; Ciobanu, 2014, p. 1466; Caparini, 2014, p. 500; Verdery, 2013, pp. 39-40; Burinskaitė \& Okuličiūtè, 2011; Mertelsmann \& Rahi-Tamm, 2009; Koehler, 1999). The targeted person usually was attacked by failures in his professional and personal life, for example, by losing his position because of feigned incompetence, inability to enter a university and study a desired profession, etc. Usually a person faced such failures even without knowing that they were organised by Secret Services. In certain cases, mostly popular in the territory of the former USSR, a person was placed in a psychiatric hospital against his or her will. The purpose of such activities was to break a person mentally by making him or her feel inadequate and to create distrust in interpersonal relations in order to achieve loyalty for the state (Horne, 2014, p. 229; Verdery, 2013; Burinskaitė \& Okuličiūtè, 2011; Gauck, 2000, pp. 20-25; Koehler, 1999).

Taking everything into account it is clear that establishing relationships with other individuals was controlled and even shaped by Secret Services under the Communist regime. This was done by introducing certain persons in the Victim's life or affecting the behavior of persons with whom the Victim was connected to either through professional or personal relations. Thus this reflects the aim of Secret Services to control the social identity of a person and establishment of relationships with other people.

After the collapse of the Communist regime, those activities ceased in postCommunist countries but as it has already been stated, the information gathered was stored by the state (Gruodyte \& Gervienè, 2015). Remembering that the mere storing of data relating to private life by public authorities involves an element of establishment of relationships with other human beings and the outside world it could be concluded that the impact on Victim's private life is still obvious. Thus the applicability of Article 8 in the case analysed here is proven. These arguments are also supported by the fact that even after the cessation of the activities of Secret Services, a Victim had to continue his/her own life with the consequences of these previous experiences (Khazanov, 2008, p. 295; Skultans, 2001, p. 339). Therefore there is high demand for the complete understanding 
of the previous events, such as the possible reasons of the past failures in private life, the value of established personal and professional relations. This is possible only through access to the Files. In addition, the knowledge of persons responsible for the victimization of a person is also important as the status of a Victim is questioned if no crime/violation has been acknowledged and the perpetrator has not been established (Hamber, 2006, pp. 576-577; Skultans, 2001, pp. 334-335; Freeman, 2000-2002, p. 115).

The second aspect of private life, that is, physical and psychological/moral integrity, might be also raised in certain cases concerning access to the Files as truth and justice are the most important elements of the mental condition of a Victim, especially in cases of gross human rights violations (Lykes \& Mersky, 2006, p. 615). Scholars also reveal that personal suffering experienced because of repressive policies of a state, which resulted in physical coercion and tortures, or direct threat of them, has serious consequences not only for the physical but also for the mental health (Pope, 2012; Gailienè, 2008; Kestenberg \& Kahn, 1998; Beiker \& Gippenreiter, 1995). However, this would not always be a case taking into account the previously described methods of Security Services that were used against Victims. This component could be established only in individual cases where a person was directly affected by gross violations of his or her basic rights.To sum up, the limited right to access Files undoubtedly involves elements forming the physical and social identity of a person under the notion of private life, as established by the ECHR, not only because of the activities of Secret Services that shaped the life of a Victim but also because of storage of these collected data by public authorities and control of access to them. Due to limitations concerning access to the Files on either ground, a Victim is not able to know who and in what manner may use information that concerns him or her, as it is impossible to expect that every person who worked for Secret Services and spied on a particular person after the collapse of the Communist regime has forgotten all the information that was accessible to him or her due to the work (Gauck, 2000, pp. 88-100). This is especially true where societies are manipulated with various selective stories about the past and collaboration with Secret Services and it seems that nobody is able to reveal the truth and a person is left with the imagined shadows and suspicions about him or her. Meanwhile, the issue of physical and psychological/moral integrity of a person could be established only in individual cases where a person was directly affected by gross violations of his or her basic rights.

Here the reasoning of the Court in the case of Avram and others v. Moldova [2011] ECHR no. 41588/05 is very important where the Court states that "the guarantee afforded by Article 8 of the Convention is primarily intended 
to ensure the development, without outside interference, of the personality of each individual in his relations with other human beings." A person should not be treated in a way that causes a loss of dignity, as "the very essence of the Convention is respect for human dignity and human freedom" (Al Nashiriv. Poland [2015]). Thus, it should be concluded that non-disclosure of the Files to a Victim clearly falls within the concept of private life because interference to the physical and social identity of a person could be demonstrated. This interference happens due to the impact on establishment of relationships with other human beings and the outside world. Once it is concluded that the issue falls within the notion of private life, the second step is evaluation if a duty to respect of private life is implemented by the state in cases when Victim fails to access the Files due to the imposed restrictions.

\section{Refusal to reveal information to the Victim in the light of respect for private life (Article 8 of the Convention)}

Countries apply different level of access towards the Files and two models, full access and limited access, are applied (Gruodyte \& Gervienè, 2015). Under both models, personal identification data are protected as part of privacy rights and a person is usually authorised to access information about him or her without disclosing personal data about other Victims. However, under the limited access model, a Victim faces additional restrictions as access to the Files is restricted because certain information in the Files is classified. To sum up, Victims fail to access the Files on two different grounds:

- certain Victim's information is protected as a personal data on the grounds of privacy rights; and

- certain Files are still kept as a classified information.

The first case concerns competing interests of individuals while the other case concerns restrictions imposed by state. Both aspects are evaluated by the authors using examples of the case law of ECHR.

\subsection{Protection of personal data on the grounds of privacy rights}

Here is a clash of different interests: the first Victim wants to implement his or her right to know the truth while the second Victim wants to protect his or her privacy. The state as the depositor of the Files has to weigh these competing interests. The research on this issue revealed that in all the post-Communist 
countries, priority was given to the interests of the second Victim, which means that the information is withheld from a Victim wishing to know the truth (Gruodytė \& Gervienè, 2015, pp. 164).

According to the established case law of ECHR, in a case of competing interests of individuals in respect for private life the doctrine of positive obligation should be invoked (Kerikmäe \& Nyman-Metcalf, 2012, pp. 43-44; Connelly, 1986, pp. 572-575). However the case law of the Court on the issue is controversial. Initially, the Court stressed the duty of a state to find the balance between competing interests, which means that there must be a procedure in which an independent authority is capable of measuring these competing interests, but later it was admitted that certain state policies withholding information from a person could prevail. This course of the case law is provided below.

In the cases of Gaskin v. the United Kingdom [1989] ECHR no. 10454/83, decided in 1989, and Odièvre v. France [2003] ECHR no. 42326/98, decided more than a decade later, the applicants were unable to access certain information concerning their childhood because of the policy of the state. ${ }^{8}$ In the case of Gaskin v. the United Kingdom [1989], violation of Article 8 was found because there was no independent authority to decide whether access had to be granted to a person wishing to become familiar with the files, created while he was under state care (the whole childhood), in cases where the persons who provided information about the child in confidence failed to answer or withheld consent. ${ }^{9}$

Meanwhile, in the case of Odièvre v. France [2003], violation of Article 8 was not found when the applicant was not able to find out the identity of her mother (access was given only to the non-identifying information about her mother and natural family), because the Court gave special consideration to the policy of France to avoid abortions and infanticide while allowing mother to remain unknown. The application of fair balance test resulted in the conclusion that mother's interest to remain unknown must prevail. Such a conclusion in this

7 Another similar case was M.G. v. The United Kingdom [2002] ECHR no. 39393/98.

8 The system of child care service in the United Kingdom "depended on the ability of those responsible for the service to obtain information [...] from private individuals - foster-parents, friends, neighbors, etc." For this system to work properly, the confidence must be guaranteed to private persons, providing information, and access to this information is denied for those that were under such care. Meanwhile, France preserved a system where a mother is allowed to remain unknown in order to avoid abortions and infanticide. As a result, the applicant was unable to obtain information about the identity of her mother and also the identity of other members of her family.

9 Similar result was reached in the case of M.G. v. The United Kingdom [2002] ECHR no. 39393/98. 
case elicited strong dissent. ${ }^{10}$ As it was stated in the dissenting opinion"[i]t is not [...] a question of determining which interest must, in a given case, take absolute precedence over others" but the balance must be found between two competing interests. Moreover, dissenting judges particularly criticised the special distinction of France's policy compared to those in the cases of Gaskin v. the United Kingdom [1989] and M.G. v. The United Kingdom [2002]. ${ }^{11}$

In the case of Guerra and others v. Italy [1998] ECHR no. 14967/89, decided by the Grand Chamber of the Court, the determination of the fact that "severe environmental pollution may affect individuals' well-being and prevent them from enjoying their homes in such a way as to affect their private and family life adversely" was enough to constitute a violation of Article 8. Here the Court did not engage in application of the fair balance test. Thus, the case of Guerra and others [1998] demonstrates that in the case of severe interference with private life, imposing serious danger to health, the failure of the state to act will be enough to find violation of positive obligation and as a result the duty to respect for private life. The same result was also reached in the case Roche $v$. The United Kingdom [2005] ECHR no. 32555/96. ${ }^{12}$

The analysed case law shows that in the case of competing personal interests concerning the disclosure of information a state has a positive obligation to ensure the balance between them. However, if a certain interest is recognised as having a serious impact on one's personal life (Guerra and others [1998]) or encompasses certain broader state policy (Odièvre v. France [2003]), such interest prevails over the other. Unfortunately, the Court does not give clear criteria for identification of the interest that must prevail because such priority was established analysing each individual case and circumstances behind it. However, it is disputable whether such a prevailing interest ever could be established as there is always a risk to miss or underestimate important circumstances, which could easily end in violation of the competence of the Court. Therefore the initial application of fair balance test to find out whether a state has established an effective procedure capable of measuring competing interests concerning disclosure of information, should prevail.

10 The decision was reached by the votes 10 to 7 .

11 In the cases of Gaskin v. the United Kingdom [1989] and M.G. v. the United Kingdom [2002] the state policy withholding disclosure of required information was aimed at proper operation of the child care service that relied on information provided by private individuals about a child in custody.

12 The applicant was unable to access information concerning his exposure to toxic chemicals during tests carried out on him at Porton Down barracks. 
Nevertheless, not every non-disclosure raises the question of violation or Article 8. In the case of Martin v. The United Kingdom [1996] the European Commission of Human Rights (First Chamber) no. 27533/95, the applicant was not able to access his medical records concerning his treatment in hospital from a permanent mental illness. As a result, referring on the decision in Gaskin v. the United Kingdom [1989] the applicant claimed violation of Article 8. Although it was recognised that medical records contained information of personal nature and Article 8 is relevant in this case, the application was declared inadmissible. The applicant failed to demonstrate that other sources to obtain the same information were not available, ${ }^{13}$ a person himself was unable to collect the required memories and that the records contained information concerning a significant period in a personal life, where particular attention was given to the fact that the Gaskin case concerned inability to access information concerning the entire childhood, that is, the main source of information about the applicant's past and formative years. Moreover, direct disclosure might be also dangerous to the applicant's health.

It could be concluded that in the case of competing interests, an inability to obtain information from other sources matters as well as the nature of a personal interest for disclosure. While this might be difficult to prove in a case where a Victim was persecuted by the Secret Services for a short period of time, this is definitely the case if the Victim's personal life was shaped by the activities of the Secret Services for decades. Moreover, it is impossible to access the materials collected by Secret Services by other means as it was already previously established that methods of surveillance were used without Victim's knowledge. Still, a fair balance test must be applied.

Thus, where a Victim has made a request not to provide information about him or her, the inability of the other Victim to access certain information will not be treated as violation of Article 8, provided that a procedure which enables to find the balance between competing interests is clearly established. None of the analysed cases in previous authors' research could be introduced as an example of such a procedure because data about the other Victim are excluded automatically (Germany) or information is not provided at the Victim's request (Lithuania, Poland) (Gruodyte \& Gervienè, 2015). ${ }^{14}$ This means that

13 The applicant could appoint a medical advisor to whom the records would be disclosed.

14 Slovakia and Bulgaria do not suggest the possibility for a Victim to exclude his or her data from disclosure to other Victims but limits this disclosure only to a name and surname of a Victim or limits form of access to such data (no copying of materials if there is no permission) (Gruodyte \& Gervienè, 2015, pp. 156-158). 
the procedure to weigh competing interests is not established in the analysed countries.

In our case, the balance of competing interests between Victims could be reached if a Victim is informed that data on him or her could be accessed by other Victims and has an option to allow unlimited access or to make disclosure subject to his or her consent in each individual case. The full prohibition to disclose Victim's records gives absolute precedence of one interest over the other and it is not clear if a certain broader state policy or adverse effect to the whole private life could be demonstrated here as in the cases Odièvre v. France [2003] or Guerra and others v. Italy [1998]. In case the Victim is absent, the availability of an independent authority to decide the question should be provided. ${ }^{15}$

Thus complete prohibition of access to certain Victim's information because it is protected as a personal data on the grounds of privacy rights might be recognised as violating the right to respect for private life of a Victim who was granted no access if there is no effective procedure to weigh competing interests of Victims.

\subsection{Concerning the information still kept as the classified information}

In countries using the limited access model, a Victim fails to access the Files because part of the information concerning his or her victimisation and identity of collaborators is still kept as classified information. The policy behind it is danger to national security. According to the second part of Article 8 of the Convention, issues of national security could justify interference with private life.

Although states have wide discretion to decide what issues fall within national security, the ECHR carefully checks if the procedural safeguards against the abuse of the power of intelligence services exist because the "powers of secret surveillance of citizens are tolerable under the Convention only in so far as strictly necessary for safeguarding the democratic institutions" (e.g., Klass and others v. Germany [1978]; Rotaru v. Romania [2000]).

Questions of national security, particularly of gathering and storing personal information as classified information and disclosure of it, were decided in the

15 In the case of Lithuania, according to the Government resolution, the Centre for the Research of the Genocide of the Lithuanian Population and Resistance Movement is such an independent authority that decides the question if a person wants to access Files when other Victim decided that information about him/her cannot be revealed (Government Resolution no. 579, 2007, Art. 7-9). 
cases Leander v. Sweden [1987] ECHR no. 9248/81, Amann v. Switzerland [2000] ECHR no. 27798/95, Rotaru v. Romania [2000] ECHR [GC] no. 28341/95, Segerstedt-Wiberg and Others v. Sweden [2006] ECHR no. 62332/00. These cases also clearly indicate that the activities of intelligence services could easily be recognised as interfering with private life even without elaboration on the notion of private life.

Generally, interference is recognised if the following conditions are satisfied: information relating to an individual's private life is stored by security services, the information is released to certain third parties and affects the person adversely. Although in the cases Leander v. Sweden [1987] and Rotaru v. Romania [2000] the personal information kept as classified information had adverse effects to the applicants because of its disclosure, ${ }^{16}$ in the case of Amann v. Switzerland [2000] the Court stated that the mere storing by a public authority of information relating to an individual's private life gathered by interception of phone calls some time ago results in interference with private life.

The case Segerstedt-Wiberg and Others v. Sweden [2006] ${ }^{17}$ particularly addressed the case of a non-disclosure of classified information about a person gathered by intelligence services for a person himself. Here the Court again confirmed the result in the case of Amann v. Switzerland [2000] concerning the applicability of Article 8 when storage of data concerning personal life by intelligence services is involved and there is no need to demonstrate that the information was released to certain third parties and this affected the person adversely.

These cases clearly indicate that the most important criterion in establishing interference with private life, when national security measures are applied, is storage of data concerning personal life by intelligence services, meanwhile

16 In the Leander v. Sweden [1987] case, the applicant was denied a position of naval museum technician because certain premises in the museum were in a military security zone and Sweden's intelligence services had not provided access to these premises for him. The applicant also was not able to access and evaluate the accuracy of information that was kept on him by the Sweden intelligence services. In the case Rotaru v. Romania [2000] the applicant, former political prisoner, was disturbed in his rehabilitation procedures because of misleading information that was provided against him by the Romanian intelligence services. Later the mistake was corrected and the applicant was rehabilitated but he was denied compensation for this.

17 This case concerned five applicants who learned that Sweden's intelligence services gathered information about them and demanded their disclosure to them because they believed that information about them was gathered and stored because of their political and social activities and not because of possible danger to national security. Part of the information was released to the applicants but they failed to access all data kept on them by Sweden's intelligence services. 
the adverse effects on private life do not necessarily need to be demonstrated. Nevertheless, this interference by the state still could be justifiable if it meets the prescribed conditions - that is, the interference is justifiable if it is "in accordance with the law" and "necessary in a democratic society" (Reid, 2004).

The standard "in accordance with the law" concerns not only an establishment of provisions in domestic law but also quality of law. The law has to satisfy certain criteria: it must be accessible, reasonably foreseeable, and compatible with the rule of law (Leander v. Sweden [1987]; Amann v. Switzerland [2000]; Rotaru v. Romania [2000]; Segerstedt-Wiberg and others v. Sweden [2006]). Compatibility with the rule of law is particularly concerned when "a power of the executive is exercised in secret" (Segerstedt-Wiberg and others v. Sweden [2006]).

However, as Karen Reid (2004) notes, when intelligence activities are aimed at national security, the requirement of foreseeability is affected by this special context. Although there is no requirement to provide all possible measures that could be applied against a person in the interests of national security, a person should nevertheless be able to identify the manner and the limits of the discretion conferred on the security services. ${ }^{18}$

Applying the established standard in situation when certain Files are still kept as

18 In the Leander v. Sweden [1987] case the Court was satisfied with the criteria of foreseeability because notwithstanding the fact that the scope of discretion of intelligence services to collect information was broad, but it was limited by certain requirements, e.g., allowing no entry about the person because of his political opinion, the information also had to be intended to serve the purpose of preventing or detecting offences against national security. The law also contained "detailed provisions as to what information may be handed out, the authorities to which information may be communicated, the circumstances in which such communication may take place and the procedure to be followed [...] when taking decisions to release information." As a result, the Court stated that "Swedish law gives citizens an adequate indication as to the scope and the manner of exercise of the discretion conferred on the responsible authorities to collect, record and release information under the personnel control system". Meanwhile in the case of Rotaru v. Romania [2000], the standard "in accordance with the law" was not satisfied and violation of Article 8 was found. The Court noted that Romanian law provided broad discretion for the intelligence services to collect records and archive information in secret files but there were no provisions laying down any limits on the exercise of those powers. Also there were no limits on the age of information held or the length of time for which it may be kept and no provision concerning "the persons authorised to consult the files, the nature of the files, the procedure to be followed or the use that may be made of the information thus obtained." This was enough to find that Article 8 was violated and the Court did not engage in further analysis whether applied measures in analysed case were "necessary in a democratic society". 
a classified information criterion "in accordance with the law" in the countries of limited access, except Romania some time ago, ${ }^{19}$ would be satisfied because laws concerning classification of certain information in the Files are duly published, provide clear description what information is kept as classified and terms for the information to be kept as a secret information (Gruodyte \& Gerviené, 2015). Thus, the aspects of accessibility, foreseeability and compatibility with the rule of law are satisfied.

Having established that the quality of law requirement is satisfied, the next step is engagement in the analysis whether applied measures are "necessary in a democratic society". Because of the aims of national security, the nature of information itself stored by intelligence services under this criterion is considered in a very limited manner as it is the discretion of national authorities. ${ }^{20}$

First of all, in order to satisfy the requirement "necessary in a democratic society", the supervision of the activities of security services, that is procedural safeguards, must be established. As it was stated by the ECHR, "[s]upervision procedures must follow the values of a democratic society as faithfully as possible, in particular the rule of law [...]. The rule of law implies, inter alia, that interference by the executive authorities with an individual's rights should be subject to effective supervision" (Rotaru v. Romania [2000]).

In the case of Leander v. Sweden [1987] although the interests of national security prevailed over the individual interests of the applicant and he was not able take the position as a museum technician, the existing procedural safeguards ${ }^{21}$ were found to be sufficient and it was recognised that there was no violation of Article 8. Meanwhile in case Segerstedt-Wiberg and others v. Sweden [2006] the Court stressed that "the interest of [a State] in protecting its national security and combating terrorism must be balanced against the seriousness of the interference

19 The case Rotaru v. Romania [2000] particularly concerned a case of classification of information concerning former activities of Secret Services under the Communist regime.

20 In the case of Rotaru v. Romania [2000] although the Court "had doubts as to the relevance to national security of the information held on the applicant," who was a former political prisoner, but noticed that it was "primarily for the national authorities, notably the courts, to interpret and apply domestic law" and respected the decision of Romanian courts that under Romanian law it is legitimate for the current intelligence services to be "depository of the archives of the former security services".

21 These procedural safeguards entailed the presence of parliamentarians on the National Police Board, the special body, participating when decision to release the information to requesting authority is taken, additional supervision was provided by the Chancellor of Justice and the Parliamentary Ombudsman as well as the Parliamentary Committee on Justice. 
with the [person's] right to respect for private life" and existence of sufficient procedural safeguards was not enough.

Here the second aspect, the age of the information, comes into play. This question was particularly addressed in the case of Segerstedt-Wiberg and Others v. Sweden [2006] where applicants were not able to receive entire information from the intelligence services that was stored as classified about them. It was established that in order to keep information as classified, a state has to demonstrate that it is relevant to current national security interests. Here the circumstances and reasons for classification of information are taken into consideration..$^{22}$

Returning to our question whether classification of certain Files could be justified as necessary in a democratic society, we must check what procedural safeguards exist in this case, that is, whether parliamentary control is sufficient on decisions concerning national security, and relevance of information to current national security interests. Here the analysis must involve each individual case as states applying the model of limited access differ in methods applied for certain Files classification (Gruodyte \& Gerviené, 2015). Therefore the Lithuanian model will be addressed. ${ }^{23}$

In July 2015, it was established that information of former collaborators who confessed their collaboration is classified for 75 years and protected according to the laws of Lithuania (Law on Lustration, 1999, Art. 8). ${ }^{24}$ The main law governing classified information and state secrets in Lithuania is the Law on the State and Official Secrets (1999), but its application is still subject to provisions

22 In this case it was found that continued storage of the information to the effect that the applicant, a journalist and author of a number of articles on Nazism and on the Security Police that attracted wide public attention, in 1969 had allegedly advocated violent resistance to police control during demonstrations was not deemed sufficient to be kept as classified and as a result not released to the applicant thirty years later. This was also the case for a members of KPML(r) (Kommunistiska Partiet MarxistLeninisterna - the Marxist-Leninist (Revolutionaries') Party, established in 1970) as the government failed to show that the party's programme clauses, advocating establishment of the domination of one social class over another by disregarding existing laws and regulations, were reflected in the actions or statements by the party's leaders or members and constituted an actual or even potential threat to national security.

23 Lithuanian regulation is chosen for the analysis because of the nationality of the authors as it can be addressed in the most accurate manner. Situation in other countries might be interpreted incorrectly due to language barrier. To avoid this, a decision was taken to limit the analysis of this particular aspect to the case of Lithuania.

24 Previously there was general statement that such data are protected according to the laws of Lithuania and the provisions of the Republic of Lithuania Law on the State and Official Secrets governing the terms were applied. 
of Law on Lustration (1999), where a precise scope of classified information in the Files is provided.

Thus the issue of parliamentary control in this case concerns only the administration of information about the people who have confessed their collaboration. As the State Security Department is the intelligence institution responsible for administering this information (Law on Lustration, 1999, Art. 5), its parliamentary control is ensured by Committee on National Security and Defence (Seimas of the Republic of Lithuania Statute 1994, Art. 63) and the Commission on the coordination of protection of state secrets (Lith. Paslapčiu apsaugos koordinavimo komisija) (Law on the State and Official Secrets, 1999, Art. 11). In the absence of any indication that the established system fails to perform its tasks, as it should in accordance with domestic law, the ECHR usually provides that the existing safeguards are sufficient and the standard of "necessary in a democratic society" is satisfied. (Reid, 2004).

The next question to be dealt with is the age of information. KGB as the institution of Secret Service in Lithuania was dissolved in 1991 (Burinskaite \& Okuličiūtè, 2011). Almost 30 years have passed since the collapse of the Communist regime in Central and Eastern Europe (Kużelewska, 2015, pp. 172). Democratic order and institutions were established in Lithuania as well as in other Central and Eastern European countries (Udovič \& Podgornik, 2016, p. 118). All these circumstances reflect complete changes in political, social and legal environment not only at national level but also at international level. Nevertheless certain Files created by the KGB are still kept as classified information and a Victim affected by the activities of a confessed collaborator would not be able to access any data in his or her lifetime related with this collaborator despite that these data also are related to a Victim.

The Law on Lustration provides that the aim to keep information about confessed former collaborators of Secret Services as a state secret is to protect these persons against blackmailing and recruitment by other intelligence services as this would impose danger to national security. Unfortunately, there is no data on how often former collaborators are blackmailed or how many attempts were made to recruit them by other intelligence services. There are also no data on how successfully the State Security Department in Lithuania fulfils its duty to uphold national security by protecting confessed former collaborators against these dangers or how successfully other countries applying the model of limited access defend their national security by classification of certain Files. 
In the absence of such data it is hard to make far-reaching conclusions whether Files that are classified are relevant to current national security interests. If the case analysed here would appear before the ECHR, the government would have to demonstrate a real possibility of danger to national security. Without such data the age of the information is a decisive factor and criterion "necessary in a democratic society" is not fulfilled thus resulting in the breach of Article 8 of the Convention.

Moreover, it is unlikely that the disclosure of an identity of former collaborators or other Files would impose more danger to national security than keeping this information as a state secret as only the disclosure could protect against blackmailing because an improper use of Files is possible only when the truth is not known in full or access to it is limited. As a result, there is no reason to keep such information as classified, especially in the light of the experience of the countries applying the model of full access.

To sum up, a failure of a Victim to access the Files because of their classification on the grounds of national security could be recognised as interference with the Victim's private life. Even though the criterion "in accordance with law" could be satisfied, such interference might not be justified under the criterion "necessary in a democratic society" if a government fails to demonstrate a real possibility of danger to national security particularly when the age of information is considered even though procedural safeguards are provided against abuse of power of intelligence services.

\section{Conclusions}

The analysis of the case law of ECHR revealed that Victim's inability to access Files concerning him or her falls within this concept of private life. The concept of private life by the Court is shaped through two basic components: physical and social identity and physical and psychological integrity. Although the Communist regime has collapsed, the impact on physical and social identity of a person is still visible as subsequent storage of data collected by Secret Services by public authorities in post-Communist countries and control of the access to them involves one of the elements forming physical and social identity of a person - that is, establishment of relationships with other human beings and the outside world. Meanwhile the impact on physical and psychological/ moral integrity of a person, that is the second aspect of the concept of private life, could be established only in individual cases where a person was directly affected by gross violations of his or her basic rights. 
After establishing that Victims fail to access the Files because certain Victim's information is protected as a personal data on the grounds of privacy rights, and certain Files are still kept as classified information, the validity of these limitations also was analysed under the case law of the Court. The results of the research revealed that the Victim's right to respect for private life might be infringed in both cases.

In case the Victim has made a request not to provide information about him or her and this results in the inability of another Victim to access certain information on him or her, there will be no violation of Article 8, provided that a procedure which enables to find the balance between competing interests is clearly established. Unfortunately, none of the states limiting Victim's access to the Files on the said grounds satisfy this requirement.

In order to comply with the case law of the Court, a state must ensure procedure where a Victim is informed that data on him/her could be accessed by other Victims and has an option to allow unlimited access or to make disclosure subject to his/her consent in each individual case of inquiry by other Victim wishing access to the same Files. In case the Victim is absent, the availability of an independent authority to decide the question should be provided. The option to prohibit disclosure of the Victim's records once and completely should not be given as this gives absolute precedence of one interest over the other and it is not clear if a certain broader state policy in limiting abilities of a Victim's to access Files in such a way could be demonstrated here.

In case access is denied because certain files of the Secret Services are still kept as the classified information, standards "in accordance with the law" and "necessary in a democratic society" for justifying interference are applied. However, they are applied slightly differently because the Court recognises wide discretion of the states in applying measures concerning national security.

The criterion "in accordance with the law" requires evaluating the quality of law under aspects of accessibility, foreseeability and compatibility with the rule of law. This criterion is satisfied in almost all countries limiting Victims' access to Files on the grounds of national security. Meanwhile, the criterion "necessary in a democratic society" requires analysis of an individual case and Lithuania was chosen as an example. Application of this criterion requires both checking of procedural safeguards against the abuse of governmental power and evaluation of relevance of information to current national security interests, taking into account the age of information and circumstances of classification.

Analysis of the case of Lithuania revealed that procedural safeguards exist and 
they are sufficient as long as there is no data that the established system fails to perform its tasks. At the same time, the relevance of applied measures to current national security interests could be hardly demonstrated because of the completely changed political and social circumstances in Lithuania and at the international level after the collapse of the Communist regime. This is even truer if there is no data that the former collaborators are blackmailed or attempts were made to recruit them by other intelligence services. Under the latter circumstances, the current situation concerning classification of Files in Lithuania does not comply with Article 8 .

Edita Gruodyte is tenure professor and vice-dean for research at the Faculty of Law of Vytautas Magnus University, Kaunas, Lithuania, with 16 years of academic and scientific experience. She is the author of more than 30 articles and a co-author of several books. Gruodyte is also a practising attorney. Her main spheres of academic interest are European criminal law, property, economic, financial and business crimes, and drug crimes.

Silvija Gerviene is a doctoral candidate and assistant at the Department of Public Law of the Vytautas Magnus University. Her doctoral thesis is being prepared on the issue of reparations for international crimes concerning the period of Soviet occupation in the Baltic States. Her main spheres of academic interest are international public and criminal law, human rights and legal ethics. She has co-authored several scientific articles on the latter spheres.

\section{References}

$A, B$ and $C$ v. Latvia [2016], ECHR, no. 30808/11.

Aksu v. Turkey [2012], ECHR, nos. 4149/04 and 41029/04.

Al Nashiri v. Poland [2015], ECHR, no. 28761/11.

Amann v. Switzerland [2000], ECHR, no. 27798/95.

Avram and others v. Moldova [2011], ECHR, no. 41588/05.

Beiker K. \& Gippenreiter Iu. B. (1995), 'The impact of Stalinist repressions of the late 1930s on the lives of three generations of families,' Russian Education \& Society, vol. 37, no. 10, pp. 52-89. https://doi.org/10.2753/RES1060-9393371052

Bensaid v. the United Kingdom [2001], ECHR, no. 44599/98.

Burinskaitė, K. \& Okuličiūtė, L. (2011), KGB slaptieji archyvai 1954-1991 m.,

Vilnius: Lietuvos gyventojų genocido ir rezistencijos tyrimo centras.

Campagnano v. Italy [2006], ECHR, no. 77955/01. 
Caparini, M. (2014), 'Comparing the democratization of intelligence governance in East Central Europe and the Balkans,' Intelligence and National Security, vol. 29, no. 4, pp. 498-522. https://doi.org/10.1080/02684527.2014.915175

Christine Goodwin v. the United Kingdom [2002], ECHR, no. 28957/95.

Ciobanu, M. (2014), 'Reconstructing the history of early Communism and armed resistance in Romania,' Europe-Asia Studies, vol. 66, no. 9, pp. 1452-1481. https://doi.org/10.1080/09668136.2014.956440

Ciubotaru v. Moldova [2010], ECHR, no. 27138/04.

Commission on Human Rights (2006), Promotion and Protection of Human Rights: Study on the right to the truth, Report of the Office of the United Nations High Commissioner for Human Rights, Symbol E/CN.4/2006/91. Retrieved from http:// www.un.org/en/ga/search/view_doc.asp?symbol=E/CN.4/2006/91 [accessed 23 Sep 2017]

Connelly, A. M. (1986), 'Problems of interpretation of Article 8 of the European Convention on Human Rights,' International and Comparative Law Quarterly, vol. 35, pp. 567-593. https://doi.org/10.1093/iclqaj/35.3.567

Costa and Pavan v. Italy [2012], ECHR, no. 54270/10.

Costello-Roberts v. the United Kingdom [1993], ECHR, no. 13134/87.

Couderc and Hachette Filipacchi Associés v. France [2015], ECHR, no. 40454/07.

Council of Europe (2017a), ‘47 Member States.' Retrieved from http://www.coe.int/en/ web/portal/47-members-states [accessed 23 Sep 2017]

(2017b), Chart of signatures and ratifications of Treaty 005: Convention for the Protection of Human Rights and Fundamental Freedoms Retrieved from https:// www.coe.int/en/web/conventions/full-list/-/conventions/treaty/005/signatures?p_ auth=UEn4XKdj [accessed 23 Sep 2017]

E.B. v. France [2008], ECHR, no. 43546/02.

European Convention on Human Rights as amended by Protocols Nos. 11 and 14, Valstybès žinios, 2011, no. 156-7390.

Evans v. the United Kingdom [2007], ECHR, no. 6339/05

Fernández Martínez v. Spain [2014], ECHR [GC], no. 56030/07.

Freeman, M. (2000-2002), 'Transitional justice: fundamental goals and unavoidable complications,' Manitoba Law Journal, vol. 28, no. 1, pp. 113-121.

Gailienė, D. (2008), Ka jie mums padaré: Lietuvos gyvenimas traumu psichologijos žvilgsniu, Vilnius: Tyto alba.

Gaskin v. The United Kingdom [1989], ECHR, no. 10454/83.

Gauck, J. (2000), Štazi bylos: kraupus VDR palikimas, transl. from German by Sigitas Asinauskas, Vilnius: Lietuvos gyventojų genocido ir rezistencijos tyrimo centras. Gillan and Quinton v. the United Kingdom [2010], ECHR, no. 4158/05.

Glass v. the United Kingdom [2004], ECHR, no. 61827/00. 
Godelli v. Italy [2013], ECHR, no. 33783/09.

Government Resolution no. 579 (2007), Resolution of the Government of the Republic of Lithuania no. 579, Valstybès žinios, 2007, no. 68-2667 as amended by Resolution of the Government of the Republic of Lithuania no. 6, Valstybès žinios, 2013, no. 4-105.

Gough v. the United Kingdom [2015], ECHR, no. 49327/11.

Gross v. Switzerland [2013], ECHR, no. 67810/10.

Gruodyte், E. \& Gervienè, S. (2015), 'Access to archives in the post-Communist countries: the victim's perspective,'Baltic Journal of European Studies, vol. 5, no. 2 (19), pp. 147-170. https://doi.org/ 10.1515/bjes-2015-0018

Guerra and others v. Italy [1998], ECHR [GC], no. 14967/89.

Haas v. Switzerland [2011], ECHR, no. 31322/07.

Hamber, B. (2006), 'Narrowing the micro and macro: a psychological perspective on reparations in societies in transition,' in P. de Greiff (ed.) The Handbook of Reparations, Oxford: Oxford University Press, pp. 560-588. https://doi. org/10.1093/0199291926.003.0017

Horne, C. M. (2014), 'Lustration, transitional justice, and social trust in post-Communist countries. Repairing or wresting the ties that bind?' Europe-Asia Studies, vol. 66, no. 2, pp. 225-254. https://doi.org/10.1080/09668136.2014.882620

I. v. the United Kingdom [2002], ECHR, no. 25680/94.

Ihsan Ay v. Turkey [2014], ECHR, no. 34288/04.

Katamidze, V. I. (2007), Loyal Comrades, Ruthless Killers: The Secret Services of the USSR 1917-1991, New York: Barnes \& Noble.

Kerikmäe, T.; Hamulak, O. \& Chochia, A. (2016), 'A historical study of contemporary human rights: deviation or extinction?' Acta Baltica Historiae et Philosophiae Scientiarum, vol. 4, no. 2, pp. 98-115. https://doi.org/10.11590/abhps.2016.2.06

Kerikmäe, T. \& Nyman-Metcalf, K. (2014), 'The Europeanization of law curricula in Eastern Partnership countries: best practices of EU Member States,' in N. Šišková (ed.) From Eastern Partnership to the Association. The Legal and Political Analysis, Newcastle upon Tyne: Cambridge Scholars Publishing, pp. 267-280. (2012), 'Less is more or more is more? Revisiting universality of human rights,' International and Comparative Law Review, vol. 12, no. 1, pp. 35-51.

Kestenberg, J. S. \& Kahn, C. (1998), Children Surviving Persecution: An International Study of Trauma and Healing, Westport: Praeger Publishers.

Koehler, J. O. (1999), Stasi: The Untold Story of the East German Secret Police, Boulder: Westview Press.

Khazanov, A. M. (2008), 'Whom to mourn and whom to forget? (Re)constructing collective memory in contemporary Russia,' Totalitarian Movements and Political Religions, vol.9, no.2-3,pp.293-310.https://doi.org/10.1080/14690760802094917 
Khmel v. Russia [2013], ECHR, no. 20383/04.

Klass and others v. Germany [1978], ECHR, no. 5029/71.

Koch v. Germany [2012], ECHR, no. 497/09.

Küchl v. Austria [2013], ECHR, no. 51151/06.

Kużelewska, E. (2005), 'How far can citizens influence the decision-making process? Analysis of the effectiveness of referenda in the Czech Republic, Slovakia and Hungary in 1989-2015, Baltic Journal of European Studies, vol. 5, no. 2 (19), pp. 171-196. https://doi.org/10.1515/bjes-2015-0019

Laduna v. Slovakia [2011], ECHR, no. 31827/02.

Law on Lustration (1999), Lietuvos Respublikos asmenu, slapta bendradarbiavusiu su buvusios SSRS specialiosiomis tarnybomis, registracijos, prisipažinimo, iskaitos ir prisipažinusiujų apsaugos istatymas [Republic of Lithuania Law on the Registration, Confession, Entering into Record of the Persons of the Republic of Lithuania Who Engaged Themselves in Secret Collaboration with the Former USSR Special Services and Protection of Those Who Confessed It], Valstybes žinios, 1999, no. 104-2976, as amended by TAR, 2015-07-03, no. 10826.

Law on the State and Official Secrets (1999), Lietuvos Respublikos valstybès ir tarnybos paslapčiu istatymas [Republic of Lithuania Law on the State and Official Secrets], Valstybés žinios, 1999, no. 105-3019 as amended by TAR, 2015-11-27, no. 18923. Leander v. Sweden [1987], ECHR, no. 9248/81.

Lillo-Stenberg and Sather v. Norway [2014], ECHR, no. 13258/09.

Lykes, M. B. \& Mersky, M. (2006), 'Reparations and mental health: psychosocial interventions towards healing, human agency, and rethreading social realities,' in P. de Greiff (ed.) The Handbook of Reparations, Oxford: Oxford University Press, pp. 589-622. https://doi.org/10.1093/0199291926.003.0018

M.G. v. The United Kingdom [2002], ECHR, no. 39393/98.

M. and M. v. Croatia [2015], ECHR, no. 10161/13.

Martin v. the United Kingdom [1996], the European Commission of Human Rights (First Chamber), no. 27533/95.

McDonald v. the United Kingdom [2014], ECHR, no. 4241/1.

Mertelsmann, O. \& Rahi-Tamm, A. (2009), 'Soviet mass violence in Estonia revisited,' Journal of Genocide Research, vol. 11, no. 2-3, pp. 307-322. https:// doi.org/10.1080/14623520903119001

Mitroiu, S. (2016), 'Recuperative memory in Romanian post-Communist society,' Nationalities Papers, https://doi.org/10.1080/00905992.2016.1182144

Munjaz v. the United Kingdom [2012], ECHR, no. 2913/06.

Nada v. Switzerland [2012], ECHR, no. 10593/08.

Niemietz v. Germany [1992], ECHR, no. 13710/88.

Nyman-Metcalf, K. (2014), 'The future of universality of rights,' in T. Kerikmäe, (ed.) Protection of Human Rights in the EU: Controversies and Challenges of the 
Charter of Fundamental Rights, Berlin Heidelberg: Springer-Verlag, pp. 21-36. https://doi.org/10.1007/978-3-642-38902-3_3

Odièvre v. France [2003], ECHR, no. 42326/98.

Oleksandr Volkov v. Ukraine [2013], ECHR, no. 21722/11.

Pope, K. S. (2012), 'Psychological assessment of torture survivors: Essential steps, avoidable errors, and helpful resources,' International Journal of Law and Psychiatry, vol. 35, pp. 418-426. https://doi.org/10.1016/j.ijlp.2012.09.017

Pretty v. the United Kingdom [2002], ECHR, no. 2346/02.

Reid, K. (2004), A Practitioner's Guide to the European Convention on Human Rights, London: Thomson: Sweet \& Maxwell.

Reklos and Davourlis v. Greece [2009], ECHR, no. 1234/05.

Roche v. the United Kingdom [2005], ECHR, no. 32555/96.

Rotaru v. Romania [2000], ECHR [GC], no. 28341/95.

Rothe v. Austria [2013], ECHR, no. 6490/07.

S. and Marper v. the United Kingdom [2008], ECHR, nos. 30562/04 and 30566/04.

Segerstedt-Wiberg and others v. Sweden [2006], ECHR, no. 62332/00.

Seimas of the Republic of Lithuania Statute (1994), Lietuvos Respublikos Seimo statutas [Seimas of the Republic of Lithuania Statute], Valstybès žinios, 1994, no. 15-249, as amended by Lietuvos Respublikos Seimo statutas "Dèl Lietuvos Respublikos Seimo statuto Nr. I-399 67, 136, 170 ir 171 straipsniu pakeitimo " [the Republic of Lithuania Statute concerning the amendment of articles 67, 136, 170 and 171 the Republic of Lithuania Statute no. I-399], TAR, 2015, no. 20274.

S.H. and others v. Austria [2011], ECHR, no. 57813/00.

Skultans, V. (2001), 'Arguing with the KGB Archives. Archival and Narrative Memory in Post-Soviet Latvia,' Ethnos: Journal of Anthropology, vol. 66, no. 3, pp. 320343. https://doi.org/10.1080/00141840120095122

Ternovszky v. Hungary [2010], ECHR, no. 67545/09.

Tysiąc v. Poland [2007], ECHR, no. 5410/03.

Udovič, B. \& Podgornik, A. (2016), 'Cultural Diplomacy of Slavic European Union Member States: A Cross-country Analysis,' Baltic Journal of European Studies, vol. 6, no. 2 (21), pp. 117-136. https://doi.org/10.1515/bjes-2016-0015

UN General Assembly (2005), Basic Principles and Guidelines on the Right to a Remedy and Reparation for Victims of Gross Violations of International Human Rights Law and Serious Violations of International Humanitarian Law. Adopted and proclaimed by General Assembly resolution 60/147 of 16 December 2005. Retrieved from http://www.ohchr.org/EN/ProfessionalInterest/Pages/RemedyAndReparation. aspx [accessed 27 Sep 2017]

Uzun v. Germany [2010], ECHR, no. 35623/05.

V.C. v. Slovakia [2011], ECHR, no. 18968/07.

Van Kuck v. Germany [2003], ECHR, no. 35968/97. 
Verdery, K. (2013), 'An Anthropologist in Communist Romania, 1973-1988, ' Problems of Post-Communism, vol. 60, no. 4, pp. 35-42. https://doi.org/10.2753/PPC1075-8216600405

Von Hannover v. Germany (No. 2) [2012], ECHR, nos. 40660/08 and 60641/08. 